\title{
AGGLUTINATION OF TYPHOID AND PARATYPHOID BACILLI BY VARIOUS IMMUNE SERA.*
}

A. M. StовеR, Fellow in Pathology, Rush Medical College.

INTRODUCTION. CONTENTS.

Technic.

Classification of Bacilli.

Consideration of Agglutinating Properties of Various Sera.

I. Typhoid Immune Sera.

A. Not agglutinating typhoid bacilli.

B. Agglutinating typhoid bacilli only.

C. Agglutinating typhoid bacilli and members of Paratyphoid Groups A and $B$.

D. Agglutinating typhoid bacilli and members of Paratyphoid Group A.

E. Agglutinating typhoid bacilli and members of Paratyphoid Group B.

II. Paratyphoid Immune Sera Produced by Members of-

Group A:

A. Not agglutinating members of Group A.

B. Agglutinating members of Group A only.

C. Agglutinating members of Groups A and B.

D. Agglutinating members of Group A and typhoid bacilli.

E. Agglutinating members of Groups A and B and typhoid bacilli. Group B:

F. Agglutinating members of Group B.

G. Agglutinating members of Groups A and B.

H. Agglutinating members of Group B and typhoid bacilli.

1. Agglutinating members of Groups A and B and typhoid bacilli.

III. Sera Immune to Members of Intermediate and Colon Groups Agglutinating Typhoid and Paratyphoid Bacilli.

Summarx.

\section{INTRODUCTION.}

Perhaps no question in recent years has aroused more interest from a practical standpoint than the diagnosis of disease by the agglutination reaction. When first applied to the diagnosis of typhoid fever, and for some time subsequently, the reliability of this procedure was unquestioned. During the general application, however, contradictory results were occasionally met with

* Received for publication April 22, 1901. 
which made it necessary to modify the interpretation of the occurrence or non-occurrence of the reaction. Since the recognition of paratyphoid fever as a distinct clinical entity caused by an organism resembling the typhoid bacillus, both culturally and in its agglutination reactions, the question of the value of such tests as a means of diagnosis of these diseases became still more complicated.

These experiments were suggested by Dr. Hektoen in January, 1903 , and at that time no satisfactory conclusions could be drawn from the diverse results reported by different investigators. A few reports throwing light upon this subject have subsequently appeared, and reference to these will be made in various parts of this paper.

My experiments concern the effect of immune human and animal sera on several strains of typhoid, paratyphoid, and colon bacilli.

\section{TECHNIC.}

The human blood was obtained by aspiration with an aseptic 10 c.c. Luer syringe from the median vein of the arm. The area was cleansed with ether followed by a 1:1,000 solution of bichloride of mercury, and 95 per cent. carbolic acid was then applied with a cotton swab over the site of puncture and allowed to remain fifteen seconds before removal with alcohol. After constricting the arm close to the shoulder, the needle was inserted into the distended vein against the current, and the blood withdrawn. The latter was placed in a sterile test-tube and allowed to stand for six hours at room temperature, after which time the serum was poured off into another sterile test-tube and kept for use.

The tedious process of obtaining rabbit's blood from a vein in the ear was early replaced by direct aspiration from the heart. The animal was carefully anesthetized with chloroform and with the usual aseptic precautions, the needle being inserted directly backward in the second right interspace close to the margin of the sternum. Ten c.c. of blood can be quickly withdrawn without deleterious effects.

The diagnosis of typhoid fever, in nearly all cases where the serum was used for experimental purposes, was confirmed by the isolation of the typhoid bacillus from the blood at the same time that the serum was collected.

The macroscopic method of agglutination was used, inasmuch as it is more practical and less laborious than the microscopic method, and bids fair to supplant the latter in clinical work as soon as its application becomes generally known. An emulsion of bacilli was prepared by washing a twentyfour hour growth from the surface of an agar slant culture with a 1 per cent. solution of $\mathrm{NaCl}$. The growth of an agar-slant culture of typhoid bacilli in 7 c.c. of solution was used as a standard of turbidity; emulsions obtained from 
the growth of more vigorous organisms were correspondingly diluted. One c.c. of an emulsion thus prepared was mixed in a 4 c.c. tube with an equal quantity of serum diluted with distilled water. Positive results were recorded when a visible formation of flocculi occurred in the mixture after standing for two hours at room temperature. In the subsequent tables the numbers represent the greatest dilutions of the sera with which positive reactions were obtained. For obvious reasons, reactions occurring in dilutions less than 1:40 are not considered. Emulsions of bacilli killed by heat or various antiseptics, formalin, thymol, etc., are nearly as effective as emulsions of living bacilli, and are obviously far more safe to handle; but as the earlier experiments were performed with living bacilli, this method was adhered to in order that the results might be uniform.

B. typh. Nos. I, IV, VI, VII, XII, XV, XXX, and 238 were typical typhoid bacilli isolated from the blood of cases of typhoid fever. B. typh. No. $V$ and B. paratyph. No. X, Eustis, Samuels, and Buxton, were obtained for me by Dr. Hektoen. B. typh. No. III and B. coli Nos. IV and $\mathrm{X}$ were furnished by Dr. Gehrman, who isolated them from the urine of typhoid patients. B. paratyph. Smith and Scott were obtained from Dr. H. G. Wells. Grateful acknowledgment is hereby made for these favors.

\section{CLASSIFICATION OF BACILLI.}

For convenience of reference, the following classification has been arranged, based principally on the work of Schottmüller, Durham, Cushing and Buxton.

\section{BACILLI MORE OR LESS MOTILE - NEGATIVE TO GRAM'S STAIN.}

(Gelatin not liquefied. Differences of growth upon agar, gelatin, and bouillon principally of degree. Potato unreliable. Indol production variable.)

B. coli group. - Ferment lactose with production of acidity in lactose bouillon. Glucose bouillon fermented in 24 hours with visible gas production. Milk coagulated. Neutral red agar-permanent yellow color in 24 hours. Indol production fairly constant.

$B$. cholerae suis, enteritidis, or intermediate group.-Lactose not fermented. Glucose bouillon fermented in 48-72 hours with visible gas production. Indol production not constant. Litmus milk initial acidity in 24-48 hours.

a) Paratyphoid group $A$. Remains acid; average 1 per cent. on tenth day; no opalescence. Neutral red agar-yellow color in 3 days; turns red in 5-7 days. Glucose bouillon fermented in 72 hours.

b) Paratyphoid group $B$. Becomes alkaline in 5 days; increases with slight opalescence in 10 days. Neutral red agar-permanent yellow in 48 hours. Glucose bouillon fermented in 48 hours. Infections clinically typhoidal.

B. typhoid group.-Lactose not fermented. Glucose fermented without visible gas production. Neutral red agar - unchanged. Litmus milk:

a) Usual type: acidity permanent.

b) "Blue" typhoid: becomes alkaline. 


\section{CONSIDERATION OF AGGLUTINATING PROPERTIES OF VARIOUS IMMUNE SERA.}

To facilitate interpretation, the results of the experiments have been grouped in the following manner:

\section{TYPHOID-IMMUNE SERA.}

A. Typhoid-immune sera which fail to agglutinate typhoid bacilli.-One of the earliest observations of this nature is by Schumacher, who, with a serum obtained at intervals during an illness of five weeks, failed to agglutinate various strains of typhoid bacilli. The typhoid bacillus was obtained from the spleen of this case post mortem. Similar observations have been made by Jürgens and Ruediger.

On the other hand, mention is also made of typhoid bacilli which failed to agglutinate with typhoid-immune 'serum. Such, for example, have been noted by Müller, who collected eight cases from the literature and added one of his own; and by Schmidt and Ruediger, each with one observation. In all of these cases the organisms became agglutinable after varying periods of cultivation, Ruediger's B. typh. No. V only during the course of my experiments. Some explanation of these phenomena is offered by Müller, who showed that bacteria grown in the presence of serum of high agglutinative value became less agglutinable; also by Conradi, who found that bacilli from the center of large colonies agglutinated more readily than those from the periphery. Interesting facts analogous to the foregoing developed during the study of B. typh. No. III, obtained from the urine of a typhoid case by Dr. Gehrman. It failed to agglutinate with the serum from three cases of typhoid fever, agglutinated with such sera in seven instances, and with paratyphoid immune sera it agglutinated in much higher dilutions than did other typhoid bacilli. (Tables I, III, V, VI, and VII.)

Immune serum produced by B. typh. No. III agglutinated this organism and paratyphoid bacilli in high dilutions, and typhoid bacilli in low dilutions only. Still more interesting is the fact that these characteristies have persisted for fourteen months, and at the time it was given me it had been cultivated upon artificial 
media for several months. Since these peculiarities are in marked contrast to the reactions obtained with other typhoid bacilli, they will not be referred to again.

B. Typhoid-immune sera with which the typhoid bacillus alone was agglutinated.-The serum of five cases of typhoid fever possessed this property, as shown by Table I:

TABLE I.

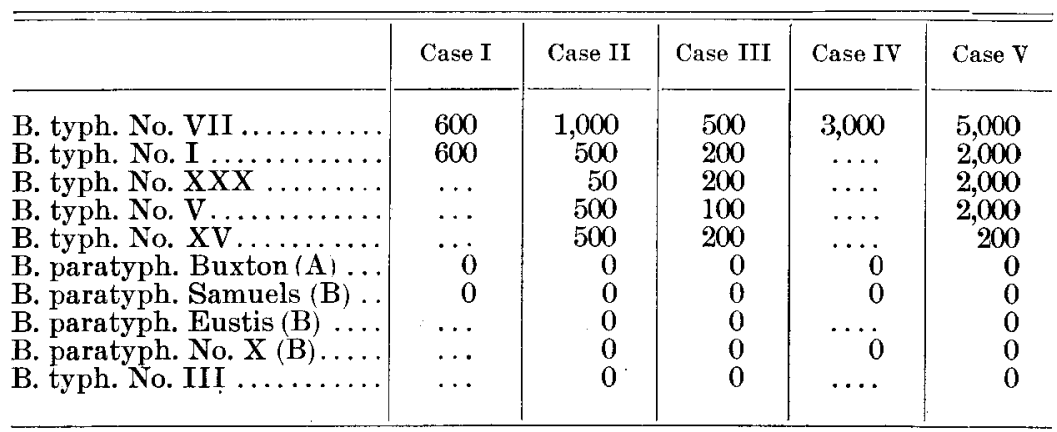

A comparison of the foregoing results with those obtained by other investigators is shown in Table II:

TABLE II.

\begin{tabular}{|c|c|c|c|c|c|c|c|}
\hline Authors & $\underset{\text { typh. }}{\mathrm{B}}$ & $\underset{\substack{\text { B. } \\
\text { para } \\
\text { ty. } \\
(A)}}{ }$ & $\underset{\substack{\text { para- } \\
\text { typh. } \\
\text { (B) }}}{\text {. }}$ & Authors & $\begin{array}{c}\text { B. } \\
\text { typh. }\end{array}$ & $\underset{\substack{\text { B. } \\
\text { para- } \\
\text { typh. } \\
(\mathbf{A})}}{ }$ & $\begin{array}{c}\text { B. } \\
\text { para- } \\
\text { typh. } \\
\text { (B) }\end{array}$ \\
\hline Gwyn & 1,100 & 0 & . & Korte... & 1,280 & 0 & 0 \\
\hline Cushing. & $\begin{array}{r}90 \\
400\end{array}$ & 0 & . & Korte... . & $\begin{array}{r}80 \\
160\end{array}$ & 0 & 0 \\
\hline Hume.. & $\begin{array}{l}400 \\
200\end{array}$ & 0 & & $\begin{array}{l}\text { Korte. } \\
\text { Korte. }\end{array}$ & $\begin{array}{l}160 \\
640\end{array}$ & $\begin{array}{l}0 \\
0\end{array}$ & $\begin{array}{l}0 \\
0\end{array}$ \\
\hline Johnston & 100 & 0 & 0 & Korte. & 2,500 & 0 & 0 \\
\hline & 50 & 0 & 0 & Korte. & 500 & 0 & 0 \\
\hline Hewlett, 6 cases. & ++ & 0 & 0 & Case I. & 600 & 0 & 0 \\
\hline Longcope, 3 cases. & 50 & 0 & 0 & Case II. & 1,000 & 0 & 0 \\
\hline Brion and Kayser. & ++ & 0 & & Case III & 500 & 0 & 0 \\
\hline Allen..... & 200 & 0 & 0 & Case IV. & 3,000 & 0 & 0 \\
\hline Korte, 2 cases.... & 40 & 0 & 0 & Case V. & 5,000 & 0 & 0 \\
\hline
\end{tabular}

In the examination of serum of animals immune to typhoid, to ascertain its power to agglutinate organisms of the typhoid, paratyphoid and colon groups, failure of these sera to agglutinate other than typhoid bacilli has been noted by Hume, Ruediger, 
and Smith, each in one case, and by Bruns and Kayser in two cases. Similar properties appearing in the sera of three rabbits are shown in Table III:

TABLE III.

Sera Examined at Varying Intervals after Subcutaneous Inoculation with Different Amounts of Bovillon Culture Twenty-Four Hours OLD.

(Rabbit No. I received 0.5 c.c.; No. II, 2.5 c.c.; No. III, 10 c.c. of B. typh. No. I. Rabbit No. IV received 4 c.c. of $B$. typh. No. VII.)

\begin{tabular}{|c|c|c|c|c|c|c|c|c|c|c|c|c|}
\hline \multirow[b]{2}{*}{ Rabbit No............ } & \multicolumn{3}{|c|}{ Normal } & \multirow{2}{*}{$\begin{array}{c}\text { After } \\
3 \\
\text { Days } \\
\text { I }\end{array}$} & \multicolumn{2}{|c|}{ After 7 Days } & \multicolumn{4}{|c|}{ After 10 Days } & \multicolumn{2}{|c|}{$\begin{array}{c}\text { After } \\
18 \text { Days }\end{array}$} \\
\hline & I & II & III & & I & II & I & II & III & IV & I & II \\
\hline 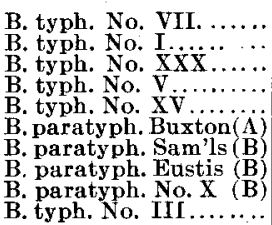 & $\begin{array}{c}\ddot{0} \\
0 \\
0 \\
0 \\
. .\end{array}$ & $\begin{array}{l}0 \\
00 \\
\because . \\
\ddot{0} \\
0 \\
0 \\
0 \\
0 \\
. .\end{array}$ & \begin{tabular}{|c|}
0 \\
0 \\
$\because$ \\
$\because$ \\
0 \\
0 \\
0 \\
0 \\
0 \\
..
\end{tabular} & $\begin{array}{r}0 \\
50 \\
0 \\
0 \\
0 \\
0 \\
0 \\
0 \\
0\end{array}$ & $\begin{array}{r}200 \\
. . \\
\ddot{80} \\
0 \\
0 \\
0 \\
0 \\
. .\end{array}$ & $\begin{array}{c}1,000 \\
. . \\
\ddot{500} \\
0 \\
0 \\
0 \\
0 \\
. .\end{array}$ & $\begin{array}{c}3,000 \\
\dddot{0} \\
500 \\
0 \\
0 \\
0 \\
0 \\
. .\end{array}$ & $\begin{array}{c}3,000 \\
\cdots \\
1,000 \\
0 \\
0 \\
0 \\
0 \\
. .\end{array}$ & $\begin{array}{r}4,000 \\
4,000 \\
4,000 \\
4,000 \\
0 \\
0 \\
0 \\
0\end{array}$ & $\begin{array}{r}1,000 \\
1,000 \\
200 \\
500 \\
\cdot . \\
0 \\
0 \\
0 \\
0 \\
0\end{array}$ & $\begin{array}{r}500 \\
1,500 \\
750 \\
750 \\
750 \\
0 \\
0 \\
0 \\
0 \\
0\end{array}$ & $\begin{array}{r}2,000 \\
3,000 \\
1,500 \\
2,000 \\
1,500 \\
0 \\
0 \\
0 \\
0 \\
0\end{array}$ \\
\hline
\end{tabular}

In addition to the demonstration of the specific action of the serum, the experiments in Table III' illustrate that the agglutinative power of the serum of the first two rabbits was not notably enhanced by increase in the amount of culture employed in single inoculations.

C. Typhoid-immune sera agglutinating both typhoid and paratyphoid bacilli.-Actual agglutination of both typhoid and

TABLE IV.

\begin{tabular}{|c|c|c|c|}
\hline \multirow{2}{*}{ Case No. } & \multirow{2}{*}{ Typhoid } & \multicolumn{2}{|c|}{ Paratyphoid } \\
\hline & & Group A & Group A \\
\hline 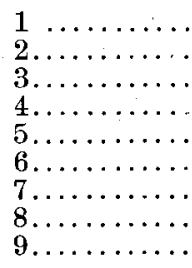 & $\begin{array}{r}320 \\
320 \\
320 \\
320 \\
1,200 \\
1,200 \\
2,500 \\
5,000 \\
5,000\end{array}$ & $\begin{array}{r}160 \\
160 \\
40 \\
80 \\
40 \\
320 \\
320 \\
320 \\
80\end{array}$ & $\begin{array}{r}160 \\
160 \\
160 \\
80 \\
160 \\
320 \\
320 \\
320 \\
320\end{array}$ \\
\hline
\end{tabular}


paratyphoid bacilli with typhoid-immune human or animal serum was obtained by Korte, and Bruns and Kayser. Korte's results were obtained with human serum, and the comparative agglutination values are shown in Table IV.

Of the human sera used in our experiments two were met with which gave similar agglutinative reactions. Their relative interagglutinability is shown by Table $\mathrm{V}$ :

TABLE V.

\begin{tabular}{|c|c|c|c|}
\hline & Case I & Five Days Later & Case II \\
\hline 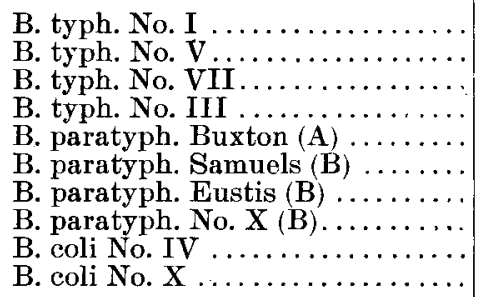 & $\begin{array}{l}500 \\
\cdots \\
\cdots \\
100 \\
200 \\
150 \\
150 \\
\cdots \\
\cdots\end{array}$ & $\begin{array}{c}500 \\
500 \\
500 \\
100 \\
0 \\
50 \\
50 \\
0 \\
\cdots\end{array}$ & $\begin{array}{r}4,000 \\
6,000 \\
6,000 \\
1,200 \\
800 \\
1,000 \\
800 \\
1,200 \\
60 \\
0\end{array}$ \\
\hline
\end{tabular}

To determine the ability of serum of any given case of typhoid fever to agglutinate other organisms, it would seem necessary to examine it at intervals during the disease, for in Case I (Table V) five days after the first examination agglutinability for the paratyphoid bacilli had almost disappeared.

One instance in which typhoid-immune animal serum manifested these interagglutinating properties is reported by Bruns and Kayser. The serum of a rabbit immunized with the anomalous B. typh. No. III manifested similar properties. B. typh. No. III was agglutinated in a dilution of 1:4,000; other typhoid bacilli, 1:80; paratyphoid bacilli of Groups $\mathrm{A}$ and $\mathrm{B}, 1: 2,000$; and B. coli No. IV, 1:60.

According to our present conceptions, the power of agglutination possessed by immune serum is due to the presence of certain bodies called agglutinins. These are somatic in origin and depend for their production upon substances contained within the bacterial cell. When two organisms are agglutinated by an immune serum produced by one of them, it is supposed that they contain similar substances, and that their agglutination is in direct ratio to the 
amounts of such substances possessed in common. The experiments of Castellani have shown that when such an immune serum is saturated with the immunizing organism, its agglutinating power is lost; whereas, if an excess of other bacteria agglutinated by this serum is added, the serum still retains an agglutinating power for the immunizing organism. On the contrary, when agglutinins are produced by several bacteria, saturation with either does not prevent agglutination of the other. Castellani, de Feyfer, Jürgens, and Korte have used this method to determine the existence or absence of mixed infections. With the demonstration that the serum of Case II (Table V) agglutinated the paratyphoid in such relatively high dilutions the possibility of a mixed infection was at once apparent. To determine this, the growths of B. typh. No. I upon three agar-slant cultures were removed with 50 c.c. of a 1 per cent. solution of $\mathrm{NaCl}$ and mixed with an equal quantity of distilled water containing 1 c.e. of the serum. Partial agglutination with precipitation occurred after two hours. The supernatant fluid was removed, filtered, and tested with paratyphoid bacilli. No agglutination occurred in the dilution of 1:200. It was therefore concluded that Case II was not an example of mixed infection, and further proof was afforded by inoculation of bouillon with the patient's blood and the isolation of bacteria from fifteen colonies on a plate made twenty-four hours later; all of these were typhoid bacilli. It cannot be assumed, however, that infection with both organisms might not have existed earlier in the disease.

Whereas, in the preceding account, agglutination was mutually manifested upon the typhoid bacillus and both groups of paratyphoid bacilli, consideration will now be given to sera with which the reaction of the latter organism was restricted to members of one group. The cases in which this selective action was manifested upon members of Group A or B are comparatively few.

D. Typhoid-immune sera agglutinating typhoid bacilli and members of Group A, but not those of Group B.-In the table accompanying Korte's work the serum of three cases showed this peculiarity. The dilutions employed were in one case 1:80; in two cases, 1:120. A similar reaction was obtained with the serum 
of a rabbit immunized with 4 c.c. of bouillon culture of B. typh. No. IV. This bacillus was agglutinated in a dilution of 1:500; B. paratyph. Buxton, a member of Group A, in a dilution of 1:100. Four members of Group B. and B. coli Nos. IV and X were not agglutinated.

E. Typhoid-immune serum agglutinating typhoid bacilli and members of Group B, but not those of Group A.- Korte met with five cases in which the above reactions were obtained. The dilutions necessary to agglutinate typhoid bacilli were two to fifteen times greater than for the paratyphoid bacilli. In twentytwo cases reported by Jürgens, and in several of our series, typhoidimmune sera were obtained which agglutinated members of paratyphoid Group B, but no tests were made with members of Group A. In some of these cases agglutination with members of Group B took place in greater dilutions than with typhoid bacilli; in some cases it occurred earlier in the disease.

\section{Paratyphoid - IMMUNe SERa.}

The recent recognition of paratyphoid fever as a clinical entity has been established largely through the study of isolated cases. In many of these the symptoms simulated those of typhoid fever; in others, the infections were local in character, resembling the sequelae of typhoid. In connection with such diverse clinical manifestations, the exact position of the exciting organism to related groups, its cultural characteristics, and the agglutinative phenomena associated with it have been the subjects of a number of studies. Perhaps the least satisfactory of these have pertained to agglutination. Of the contributions relating to the latter, one of the most important is that of Buxton, who experimented with numerous strains of paratyphoid and related bacilli, and various animal immune sera in arbitrary dilutions of 1:400, and concluded that interagglutination of the various groups does not occur. Careful observations of the agglutinative properties of paratyphoid bacilli made since Buxton's communication have emphasized the necessity of using many dilutions. These observations, together with those of the writer, will be considered as follows: 
A. Sera produced by members of paratyphoid Group A not agglutinating other members of the group. - Very interesting facts are contained in the history of an organism found by Cushing in the pus of a post-paratyphoidal osteomyelitis. It agglutinated with the patient's serum and that of a rabbit immunized with it. Neither of these sera agglutinated Gwyn's organism, another member of the group. Durham, with an immune serum produced by Gwyn's organism, and Johnston, using the serum from two cases of paratyphoid fever cansed by members of Group A, also failed to agglutinate Cushing's organism. One year later Longcope, testing the serum of a case of paratyphoid fever, agglutinated Cushing's bacillus in dilutions of 1:200 and Gwyn's in a dilution of 1:500; and Buxton has since reported that Cushing's organism had acquired agglutinability common to its group. Previously in this article mention has been made of typhoid bacilli which, failing to agglutinate with typhoid-immune serum for a time, have later acquired this property. These instances and the behavior of Cushing's organism would suggest that delayed agglutinability may not prove uncommon.

B. Sera produced by members of Group A agglutinating members of this group only.--In four observations - Gwyn, Brion, Kayser, and Hume - the attempts to agglutinate other organisms were limited to typhoid bacilli, and none of these were successful. Bruns and Brion, working with Kayser, were unable to agglutinate typhoid and colon bacilli, or those of Group B, with the serum of a rabbit immunized with a bacillus belonging to Group A. Johnston with three human immune sera agglutinated five members of Group A, as well as one obtained from the blood of one of the cases, but could not agglutinate bacilli of the colon, typhoid, or intermediate groups.

C. Sera produced by members of Group A agglutinating members of Groups $A$ and B.- In the experiments with sera immune to typhoid bacilli it was noted that the majority of them exerted a selective action upon members of the typhoid group. The preceding discussion (B) has shown that serum immune to members of paratyphoid Group A possesses similar properties in relation to that group. It therefore has been interesting to ascer- 
tain if the latter manifests other properties analogous to those of the typhoid-immune sera which agglutinated members of related groups. Serving to establish this point is a report by Schottmüller of two human immune sera, one of which agglutinated another member of Group A and three members of Group B, the other agglutinated two members of Group B. Smith and Scott, each with the serum of a rabbit immunized with Buxton's bacillus, obtained agglutination with members of both groups. None of these sera agglutinated typhoid or colon bacilli. In my own experiments, agglutination tests were made with a rabbit serum similar to that used by the last two writers, and corresponding results were obtained. B. paratyph. Buxton (A) was agglutinated in a dilution of $1: 8,000$; B. paratyph. Eustis and No. $_{0} \mathrm{X}(\mathrm{B})$, $1: 6,000$; B. paratyph. Samuels (B), 1:4,000. Five strains of typhoid bacilli were not agglutinated.

Previous mention was made that Buxton was unable to agglutinate members of Group B with immune rabbit serum produced by inoculation with his organism. These results show that after several years the same bacillus has acquired the power of producing a serum which readily agglutinates members of Group B.

D. Serc produced by members of Group A agglutinating members of this group and typhoid bacilli.--Observations of this character have been made in only one instance. Cushing, with the serum of a rabbit immunized to his organism, obtained agglutination with typhoid bacilli. $(1: 200)$, and also members of the intermediate group other than paratyphoid.

E. Sera produced by members of Group A agglutinating members of Groups $A$ and $B$ and typhoid bacilli.-No cases have been reported in which such an interagglutination was obtained.

Of the observations here recorded we note that in seventeen instances, where agglutination reactions of serum immune to bacilli of Group A were tried with typhoid bacilli, only one positive result was obtained; and in eleven cases, where tests were made with members of Group B, five positive results were obtained. Obviously, these observations are too few to warrant positive conclusions. 
The numerous experiments dealing with sera immune to members of Group B will be considered as follows:

F. Sera produced by members of Group $B$ agglutinating members of this group only. - Ruediger reported two cases of paratyphoid fever due to members of this group in which the serum did not agglutinate typhoid bacilli. Pratt made a similar observation in one case, and Conradi, Drigalski and Jürgens in altogether four cases. Kayser experimenting with the serum of three cases of paratyphoid fever obtained agglutination with members of Group B, but not with members of Group A or the typhoid group. De Feyfer obtained like results in six cases. Korte with a similar serum could not obtain agglutination with members of the typhoid intermediate or colon groups. Pratt, using the serum of an animal immunized with a member of Group B, could not agglutinate typhoid bacilli.

G. Sera produced by members of Group $B$ agglutinating members of this group and Group A.-Instances of this nature are reported by several observers. Schottmüller in three experiments with such sera was able to agglutinate members of Groups $\mathrm{A}$ and $\mathrm{B}$, but not bacilli of the typhoid and colon groups. Longcope in three cases, and Allen in two cases, agglutinated members of Group A, but not typhoid bacilli. A similar reaction was observed with animal serum by Scott; with the serum of a rabbit immunized with his paratyphoid organism agglutination was obtained with nembers of Group A, but not with members of typhoid or colon groups, or other intermediate organisms. I have obtained exactly the same results with this organism.

$\mathrm{H}$. Immune serc produced by members of paratyphoid Group $B$ agglutinating members of that group and typhoid bacilli.-- Observers reporting reactions of this character are Conradi, Drigalski and Jürgens, in twenty-six cases examined during an epidemic at Saarbrück; Hünermann, in nineteen cases of another epidemic; Lucksch in two cases; and Libman in one case. In two instances, Libman's and one of the Saarbrück series, typhoid bacilli were agglutinated in higher dilutions than were members of Group B, and the possibility of a mixed infection was questioned. In Libman's case, one of cholecystitis, the 
diagnosis of a paratyphoid infection was based on the isolation from the blood of a bacillus belonging to Group B. The serum examined later in the disease had lost its power of agglutinating members of Group B, but still agglutinated typhoid bacilli. The diagnosis of the second case mentioned was established by isolation, from the stools, of bacilli having characteristics of Group B. In neither case can diagnosis of mixed infection be absolutely excluded.

Jürgens alone and with Conradi and Drigalski obtained, from two rabbits immunized with members of Group B, sera which agglutinated typhoid bacilli. Bruns and Kayser, and Korte, obtained like results with similar immune rabbit's serum; the latter, however, also agglutinated members of colon and intermediate groups.

I. Immune serc produced by members of Group $B$ agglutinating members of Groups $A$ and $B$ and typhoid bacilli.-Two human sera have been observed which have manifested agglutination reactions of this character-one by Schottmüller, and another by Korte. That observed by the latter also agglutinated other members of the intermediate group. No agglutination with colon bacilli was obtained. Korte, with the serum of two immune rabbits, was able to agglutinate members not only of Groups A

TABLE VI.

Immune Rabbit Sera Obtained Fourteen Days after Subcutaneous Inoculation with 4 c.c. of Twenty-four Hour Bouillon Cultures of Bac. paratyph. Smith, Eustis, and No. X, Grove B.

\begin{tabular}{|c|c|c|c|}
\hline & Smith & Eustis & No, $\mathrm{X}$ \\
\hline 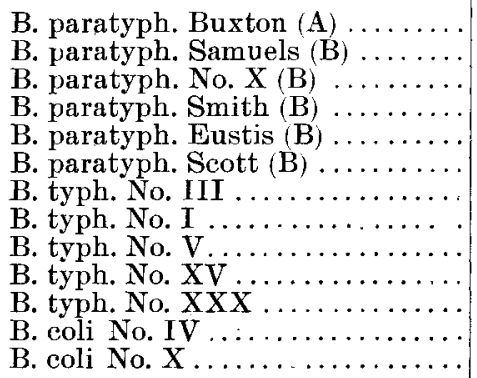 & $\begin{array}{r}200 \\
\cdots \\
200 \\
500 \\
200 \\
0 \\
10 \\
50 \\
50 \\
0 \\
\cdots\end{array}$ & $\begin{array}{r}500 \\
500 \\
500 \\
200 \\
200 \\
200 \\
50 \\
50 \\
50 \\
50 \\
\cdots\end{array}$ & $\begin{array}{r}6000 \\
8,000 \\
6,000 \\
6,000 \\
6,000 \\
60 \\
0 \\
0 \\
50 \\
50 \\
0\end{array}$ \\
\hline
\end{tabular}


and B and the typhoid group, but also of the colon and intermediate groups. In our series of experiments with rabbits immunized with members of Group B, three sera were obtained which agglutinated members of Groups A and B and typhoid bacilli. These results are shown in Table VI.

\section{COLON AND OTHER IMMUNE SERA.}

It has been observed that certain of the typhoid- and paratyphoid-immune sera have agglutinated members of the colon and intermediate groups, and it is important to ascertain whether sera immune to members of these groups will agglutinate typhoid and paratyphoid bacilli. Exhaustive contributions have been made in regard to the action of these sera on typhoid bacilli and the experiments of Castellani, Durham, Bruns and Kayser, Stern, Biberstein, Rothberger, and Theobald Smith demonstrate that typhoid bacilli are occasionally agglutinated with serum produced by members of the colon and intermediate groups.

The experiments relative to the action of these sera on paratyphoid bacilli are less numerous. Scott failed to agglutinate his member of Group B with the serum of two rabbits immunized with B. enteritidis and B. dysenteriae, respectively. Hume reports the failure of members of Group $A$ to agglutinate with the serum of a rabbit immune to $\mathrm{B}$. enteritidis. Cushing, however, obtained a serum from a rabbit immunized with B. chol. suis, which did agglutinate a member of Group A. G. B. Smith, with the serum of two rabbits immune to B. chol. suis and B. enteritidis, failed to obtain agglutination with members of either group.

Three reports-Hume, Bruns and Kayser, and Scott-concern the action of serum immune to members of the colon group on paratyphoid bacilli, and in none of these did agglutination occur.

Table VII shows the results obtained with serum immune to the two colon bacilli used in our experiments. The organism B. coli No. IV, which at times agglutinated with paratyphoid- and typhoid-immune sera, produced a serum which agglutinated these bacilli, whereas serum immune to B. coli No. X did not acquire this property. 
TABLE VII.

Colon-Immune Rabbit Sera Obtained Fourteen Days after Subcutaneous Inoculation with 4 o.c. Twenty-Four Hour Bouillon CultURE of B. COLI Nos. IV and $X$.

\begin{tabular}{|c|c|c|}
\hline & B. coli No. IV & B. coli No. $\mathrm{X}$ \\
\hline $\begin{array}{l}\text { B. coli No. IV } \ldots \ldots \ldots \ldots \\
\text { B. coli No. X } \ldots \ldots \ldots \ldots \\
\text { B. paratyph. Buxton }(\mathrm{A}) \\
\text { B. paratyph. Eustis }(\mathrm{B}) \ldots \\
\text { B. paratyph. Samuels }(\mathrm{B}) \\
\text { B. paratyph. No. X }(\mathrm{B}) \ldots \ldots \\
\text { B. typh. No. I } \ldots \ldots \ldots \ldots \\
\text { B. typh. No. } \ldots \ldots \ldots \\
\text { B. typh. No. XV } \ldots \ldots \ldots \\
\text { B. typh. No. XXX } \ldots \ldots \\
\text { B. typh. No. III } \ldots \ldots \ldots\end{array}$ & $\begin{array}{r}1,000 \\
0 \\
60 \\
80 \\
60 \\
80 \\
60 \\
40 \\
40 \\
0 \\
150\end{array}$ & $\begin{array}{r}500 \\
0 \\
0 \\
0 \\
0 \\
0 \\
0 \\
0 \\
0 \\
0 \\
0\end{array}$ \\
\hline
\end{tabular}

Further experiments of this character will probably show that paratyphoid bacilli interagglutinate with colon and other immune serum to the same, or even a greater, extent than do typhoid bacilli.

\section{SUMMARY.}

A review of these results would suggest that certain phases of this subject require still further investigation before the question of interagglutination of bacilli of the typhoid and paratyphoid group can be placed on a reliable basis. Relative to this fact should be mentioned that a number of the paratyphoid bacilli reported have occasionally manifested cultural reactions which differed from those characterizing the group in which they have been placed. Some of these irregularities may be explained by different environments, or variations in the culture media used by the various observers, but they nevertheless constitute evidence that hard and fast lines cannot be established between the typhoid, paratyphoid, and other intermediate groups.

If, in the light of our present knowledge, a precise classification of these bacilli into groups cannot be arranged, we should not expect to make definite conclusions in regard to the interagglutination of members of these groups. It must therefore be acknowledged that the most reliable means of diagnosis is the study not only of the exciting organism isolated from the blood 
or feces with agglutination tests, but also of cultural characteristics, for it has been shown that the diagnosis of bacilli by the agglutination tests, as established by several investigators reporting results of blood cultures, is untrustworthy.

The difficulties encountered in the isolation of the cansative bacillus, and the impossibility of isolation in the later stages of the disease have led, as before stated, to the use of agglutination reaction as a convenient and presumably accurate test. The results of these experiments have not established the inaccuracy of this procedure, as would at first appear, but have emplasized the necessity of modifying the prevailing interpretations of the occurrence or non-occurrence of the reaction.

It has been assumed that agglutination of typhoid bacilli by a suspected serum in a dilution of $1: 100$ by the microscopic method, or of 1:50 by the macroscopic method, is an indication of infection with this organism. However, as shown in the foregoing, serum immune to members of other groups may also agglutinate the typhoid bacillus in the same, and even higher, dilutions, and a test with such bacilli, especially those of paratyphoid Groups A and B, should be performed. Ordinarily the paratyphoid organisms require from ten to thirty times more serum for their agglutination than do typhoid bacilli, and if reactions of the suspected serum with these occur in relatively high dilutions, the saturation test is necessary to decide which is the organism producing the infection.

If repeated agglutination tests made at intervals in a suspected case prove negative with both typhoid and paratyphoid bacilli, it either denotes infection with some other organism, or possibly may be analogous to the reported cases in which typhoid bacilli were isolated from the blood or stools, and no agglutination of other typhoid bacilli occurred with the patient's serum.

In suspected cases of paratyphoid fever, agglutination of members of both groups should be tried, as serum immune to members of one may not agglutinate members of the other group. In other instances serum immune to members of either group may agglutinate the typhoid bacillus in high dilutions, and here again the saturation test is necessary. Some of these difficulties may 
be avoided by using for the tests bacilli which are known to agglutinate only with serum immune to members of their own group. In the event that representatives of the various groups are not at hand, diagnosis by means of the agglutination test may be exceedingly difficult. It is to be hoped that in the near future a technic will be perfected by which will be obtained reactions which are sufficiently delicate and specific to restore the agglutination test to a comparatively simple procedure.

I wish to express my sincere thanks to Dr. Hektoen and Dr. LeCount for their valuable advice and suggestions, and to the members of the resident staff of Cook County Hospital for their co-operation and assistance in obtaining the blood used in these experiments.

\section{REFERENCES.}

Achard and Bengaude. Bull. et mémoirs de la Soc. de Méd. des Hôp., 1896, p. 838.

Allen. Am. Jour. Med. Sci., 1903, 125, p. 96.

Bieberstein. Ztschr.f. Hyg., 1898, 27, p. 347.

BRION AND KaYser. Münch. med. Wchnschr., 1902, 15, p. 611.

BRUNS AND KaYser. Ztschr.f. Hyg., 1903, 44, p. 402.

Buxton. Jour. Med. Rsch., 1902, 3, p. 201.

Castellani. Ztschr.f. Hyg., 1902, 40, p. 1.

Conradi, Drigalski, AND Jürgens. Ibid., 1903, 42, p. 141.

Cushing. Bull. Johns Hopkins Hosp., 1900, 2, p. 156.

DURhaM. Jour. Exp. Med., 1901, 5, p. 353.

DE FEYFER AND KAYSER. Münch. med. Wehnschr., 1902, 41, p. 1692.

Fodor and Rigler. Centralbl.f. Bakt., 1898, 23, p. 930.

Gwys. Bull. Johns Hopkins Hosp., 1898, 9, p. 54.

Hewlett. Am. Jour. Med. Sci., 1902, 124, p. 200.

Hume. Report Thompson Yates Lab., 1902, 4, p. 385.

HÜNERMANN. Ztschr.f. Hyg., 1902, 40, p. 522.

Johnston. Am. Jour. Med.Sci., 1902, 124, p. 187.

JÜRGENS. Ztschr. f. Hyg., 1903, 43, p. 372.

KAYSER. Deutsche med. Wchnschr., 1903, 18, p. 311.

KoRte. Ztschr.f. Hyg., 1903, 44, p. 243.

KURTH. Deutsche med. Wchnschr., 1901, 30, p. 500.

Libman. Jour. Med. Rsch., 1903, 3, p. 168.

LongCope. Am. Jour. Med. Sci., 1902, 124, p. 209.

Lucksch. Centralbl. f. Bakt., 1903, 34, p. 113.

MëLleR. Münch. med. Wchnschr., 1903, 2, p. 56.

PratT. Boston Med. and Surg. Jour., 1903, 148, p. 137.

Rothberger. Ztschr.f. Hyg., 1900, 34, p. 79.

RUEdiger. Trans. Chicago Path. Soc., 1903, 5, p. 187. 
Sснмірт. Wiener klin. Wehnschr., 1902, 49, p. 1297.

SсноттMÜLLER. Deutsche med. Wchnschr., 1900, 32, p. 511; Ztschr. f. Hyg., 1901, 36, p. 368.

Schumacher. Ztschr.f. Hyg., 1898, 30, p. 364 .

Sсотт. Jour. Infect. Dis., 1904, 1, p. 72.

Бмгтн, G. B. Jour. Am. Med. Assn., 1903, 41, p. 1470.

Sмiтн, Theobald. Jour. med. Rsch., 1903, 4, p. 270.

Stern. Centralbl. f. Bakt., 1898, 23, p. 673.

Widal and Nobécourt. Semaine médicale, 1897, p. 285. 